\title{
INTEGRASI SERVQUAL DAN KANO MODEL KE DALAM QUALITY FUNCTION DEPLOYMENT SEBAGAI UPAYA PENINGKATAK KUALITAS PELAYANAN INSTALASI RAWAT JALAN RUMAH SAKIT UMUM DAERAH IBNU SINA GRESIK
}

\author{
Yogi Yusron Arif ${ }^{\text {1) }}$, Pregiwati Pusporini ${ }^{2)}$, Elly Ismiyah ${ }^{3)}$ \\ ${ }^{1}$ Mahasiswa Teknik Industri, Fakultas Teknik, Universitas Muhammadiyah Gresik \\ ${ }^{2,3}$ Dosen Teknik Industri, Fakultas Teknik, Universitas Muhammadiyah Gresik \\ Jl. Sumatera No. 101 GKB - Gresik 61121 \\ e-mail : yogiyusron@gmail.com
}

\begin{abstract}
ABSTRAK
RSUD Ibnu Sina gresik merupakan rumah sakit umum daerah di Gresik yang dituntut untuk terus meningkatkan kualitas pelayanannya dengan berpedoman pada Survei Kepuasan Masyarakat (SKM) sebagai indikator kinerja utama. Berdasarkan laporan kinerja instansi pemerintah, SKM dari rumah sakit khususnya pada instalsai rawat jalan mengalami penurunan secara signifikan di dua klinik pada 4 semester terakhir yaitu periode 2017 sampai 2018, yang mengakibatkan target tahunan indeks kepuasan masyarakat (IKP) untuk tiap klinik tidak tercapai di semester akhir tahun 2018. Untuk itu pihak rumah sakit perlu melakukan evaluasi untuk meningkatkan kualitas pelayanan didasarkan pada keinginan pelanggan. Penelitian ini bertujuan untuk mengetahui tingkat kepuasan pasien, mengetahui kategori atribut pelayanan dan memberikan usulan perbaikan kualitas pelayanan pada dua klinik di instalasi rawat jalan yang tidak mencapai target IKP tahun 2018. Metode yang digunakan dalam penelitian ini adalah menggabungkan metode servqual dan kano model ke dalam quality function deployment. Servqual diguanakan untuk mengetahui kesenjangan harapan dan kenyataan, kano model untuk pengkategorian atribut dan QFD sebagai usulan perbaikan. Berdasarkan hasil penelitian didapatkan 21 atribut pelayanan, dimana terdapat 17 atribut yang memiliki gap negatif di klinik jantung dengan 2 atribut berkategori attractive, 8 one-dimensional, 7 must-be dan 14 atribut di klinik kandungan dengan 2 atribut berkategori attractive, 5 one-dimensional dan 7 must-be. Sehingga terdapat 17 atribut di klinik jantung dan 14 atribut di klinik kandungan yang menjadi voice of customers. Dari hasil analisis QFD terdapat 9 respon teknis dengan 5 prioritas teratas menjadi upaya perbaikan yaitu penyelenggaraan pendidikan dan pelatihan, briefing orientasi kualitas pada tenaga medis, program tenaga medis dan petugas terbaik, rehabilitasi fasilitas gedung dan peralatan pendukung dan pemberian kotak saran dan aduan.
\end{abstract}

Kata Kunci : Kepuasan pasien, Klinik, Rumah Sakit, Servqual, Kano Model, QFD

\section{PENDAHULUAN}

Rumah Sakit Umum Daerah (RSUD) merupakan salah satu unit di Badan Layanan Umum Daerah yang menyelenggarakan layanan publik di bidang kesehatan. Sebagai suatu bentuk pelayanan publik (diselenggarakan oleh pemerintah) RSUD dituntut untuk menerapkan prinsip good governance. RSUD Ibnu Sina adalah rumah sakit umum daerah kabupaten gresik yang memiliki sasaran strategis yaitu meningkatkan kualitas pelayanan Rumah Sakit dengan indikator kinerja utama Nilai Survei Kepuasan Masyarakat (SKM) yang merupakan persepsi pasien terhadap kualitas pelayanan yang diberikan dan Tingkat Akreditasi yang diselenggarakan dua kali dalam satu tahun yang tercermin dalam perjanjian kinerja tahunan dengan target Indeks Kepuasan Pelanggan 80\% pada tahun 2020 (LKIP, 2018).

Pengukuran kepuasan pelanggan dilakukan dua kali dalam satu tahun sebagai langkah evaluasi sebagai bagian dari penerapan Keputusan Menteri Pendayagunaan Aparatur Negara Nomor 16 tahun 2014 tentang pedoman survei kepuasan masyarakat unit pelayanan instansi pemerintah, kinerja pelayanan suatu jasa layanan publik perlu diukur secara berkala sebagai upaya meningkatkan kinerja dan kualitas pelayanan secara terus-menerus dan berkelanjutan. Berdasarkan survei kepuasan 
pelayanan di instalasi rawat jalan terdapat 2 klinik yang mengalami indek kepuasan pelayanan yang menurun secara signifikan dari tahun 2017-2018 dalam kurun 4 semester yang mengakibatkan tidak tercapainya target tahunan pada semester 2 tahun 2018. Grafik penurunan kepuasan pasien selama 4 semester pada klinik jantung dan kandungan dapat dilihat pada Gambar 1

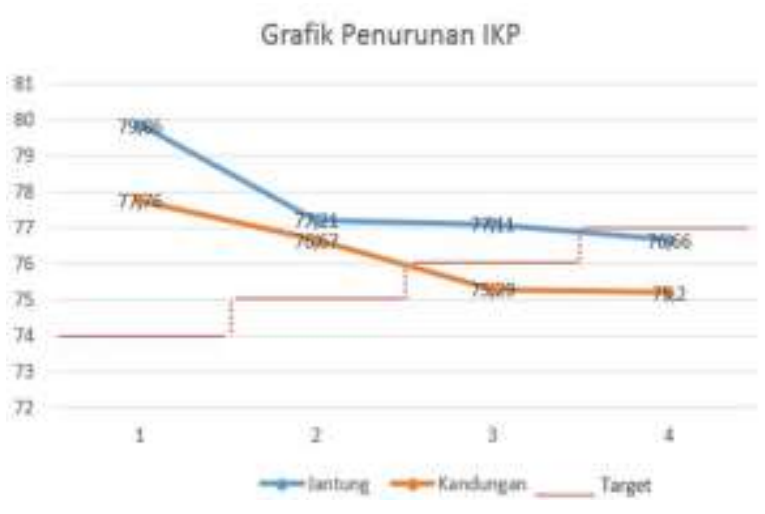

Gambar 1 Grafik Penurunan IKP

Berdasarkan LKIP, Nilai Target akhir renstra RSUD ibnu sina gresik tahun 2016 adalah Indeks Kepuasan Pelanggan (IKP) mencapai $80 \%$ pada tahun 2020 dan untuk target IKP pada semester 2 di tahun 2018 adalah 77\%. Untuk itu, rumah sakit perlu mengetahui apa yang menjadi harapan pasien agar dapat memberikan kinerja sesuai dengan harapan pasien tersebut.

Dari hasil survei awal yang dilakukan pada 2 klinik/unit yang mengalami penurunan kepuasan pelayanan sebagian besar pasien masih mengeluhkan beberapa hal yaitu: dokter yang datang tidak sesuai jadwal, proses pemeriksaan yang lama sehingga pasien banyak menunggu di ruang pemeriksaan, kursi ruang tunggu yang masih kurang dan kursi ruang tunggu yang tidak nyaman. Dampaknya akan tidak tercapainya target IKP 80\% pada tahun 2020 dan kepuasan pasien terhadap pelayanan rumah sakit akan semakin menurun sehingga berdapak pada reakreditasi rumah sakit yang salah satu prasyaratnya bergantung pada capaian IKP yang sesuai dengan standart yang telah ditetapkan.
Maka dari itu perlu dilakukan tindakan perbaikan sehingga trend penurunan dapat diatasi, pasien mendapatkan pelayanan sesuai dengan yang diharapkan dan target IKP dapat tercapai.

\section{A. Rumusan Masalah}

Berdasarkan pada latar belakang masalah, maka rumusan masalah dalam penelitian ini adalah :

1. Apakah persepsi pasien klinik jantung dan kandungan di instalasi rawat jalan RSUD ibnu sina telah sesuai dengan yang diharapkan?

2. Berdasarkan performa kualitas dan klasifikasi atribut-atribut pelayanan, atributatribut pelayanan apa saja yang perlu dipertahankan, diperbaiki dan ditingkatkan kualitasnya?

3. Langkah-langkah apa yang harus dilakukan oleh klinik jantung dan kandungan di instalasi rawat jalan rumah sakit sebagai upaya peningkatan kualitas pelayanannya ?

\section{B. Tujuan Penelitian}

Tujuan dari penelitian ini adalah :

1. Untuk mengidentifikasi bagaimana pelayanan di klinik jantung dan kandungan di instalasi rawat jalan dilihat dari persepsi dan harapan pasien.

2. Untuk mengidentifikasi atribut-atribut pelayanan apa saja yang perlu di pertahankan, diperbaiki dan di tingkatkan kualitasnya berdasarkan performa kualitas dan klasifikasi atribut-atribut pelayanan.

3. Untuk mengidentifikasi langkah-langkah apa yang harus dilakukan oleh instalasi rawat jalan rumah sakit sebagai upaya peningkatan mutu pelayanan.

\section{TINJAUAN PUSTAKA}

\section{A. Kualitas}

Pakar kualitas ternama W. Edwards Deming (1993) dalam Irwan \& Haryono (2015) 
menyatakan bahwa kualitas tidak berarti yang terbaik pemberian kepada pelanggan tentang apa yang mereka inginkan dengan tingkat kesamaan yang dapat diprediksi serta ketergantungannya terhadap harga yang mereka bayar.

\section{B. Kepuasan Pelanggan}

Kepuasan (Satisfaction) dapat diartikan sebagai sebuah upaya pemenuhan sesuatu atau membuat sesuatu memadai (Tjiptono \& Candra, 2016). Contrast Theory memberikaan asumsi bahwa pelanggan akan membandingkan kinerja sebenarnya dengan ekspektasi pra-pembelian. Ketika sebuah kinerja aktual sesuai atau lebih besar dari ekspektasi maka pelanggan akan puas dan sebaliknya, ketika kinerja yang sebenarnya lebih rendah dari harapan pelanggan, maka pelanggan akan tidak puas. Evaluasi purna beli akan menjadi fungsi yang positif dari harapan pelanggan pra-pembelian

\section{Jasa}

Jasa merupakan kegiatan, perbuatan, atau kinerja yang bersifat tidak nampak (Ariani, 2009). Secara garis besar, konsep jasa mengacu pada tiga lingkup definisi utama: industri, output atau penawaran, dan proses (Tjiptono \& Candra, 2016), jasa memiliki empat karakteristik yang unik yang membedakan dari barang. Keempat karakteristik utama tersebut dinamakan paradigma IHIP yaitu :

1. Intangibility

2. Heterogenety/Variability

3. Insparability

4. Perishability

Strategi jasa akan memberikan suatu pandangan mengenai jasa seperti apa yang harus diberikan oleh perusahaan.

\section{Kualitas Jasa/Service Quality (Servqual)}

Servqual merupakan model yang digunakan untuk mengukur kualitas layanan yang dirancang untuk mengidentifikasi dimensi secara akurat untuk mengetahui ukuran kualitas layanan
(Kendampully \& Solnet, 2015). Konsep Servqual digunakan untuk menghitung gap antara persepsi pelanggan terhadap jasa yang dikurangi dengan nilai ekspektasi atau harapan pelanggan (Wijaya, 2018). Berikut adalah persamaanya :

$$
\begin{gathered}
Q=\mathrm{P}(\text { Perceived service })-\mathrm{E}(\text { Expected } \\
\text { service })
\end{gathered}
$$

Dimana :

$Q:$ Kualitas Pelayanan (quality of service)

P : Persepsi pelanggan

E : Harapan pelanggan pada jasa

Menurut Parasuraman, et al. (1985) dalam model tersebut terdapat lima kesenjangan (gap) yang menyebabkan kegagalan penyampaian jasa (Tjiptono \& Candra, 2016). Gap tersebut meliputi

1. Gap-1. merupakan kesenjangan antara harapan pelanggan dan persepsi pihak perusahaan (knowledge gap)

2. Gap-2, merupakan kesenjangan antara persepsi manajemen perusahaan terhadap harapan pelanggan dengan spesifikasi kualitas jasa (standards gap).

3. Gap-3, adalah kesenjangan antara spesifikasi mutu pelayanan dengan pemberian pelayanan terhadap pelanggan (delivery gap).

4. Gap-4, merupakan kesenjangan antara pemberi pelayanan jasa dan komunikasi eksternal perusahaan (communication gap).

5. Gap-5, adalah kesenjangan antara harapan pelanggan dengan kenyataan pelayanan yang diterima (service gap).

Untuk menghitung nilai kepuasan pelanggan dapat digunakan rumus di bawah ini (Tjiptono \& Candra, 2016) :

\section{Satisfaction Score $=$ Gap Score $(Q)$ x Tingkat Kepentingan}

Terdapat lima dimensi utama jasa yang disusun sesuai urutan tingkat kepentingan 
relatifnya menurut Parasuraman, et al. (1985) dalam Kendampully \& Solnet (2015) sebagai berikut :

1. Reliability (reliabilitas)

2. Tangibles (bukti fisik)

3. Responsiveness (daya tanggap)

4. Assurance (jaminan)

5. Emphaty (empati)

\section{E. Kano Model}

Model ini bertujuan untuk mengkategorikan atribut-atribut produk atau jasa yang mempu memenuhi kebutuhan pelanggan dalam beberapa kategori, kepuasan pelanggan merupakan fungsi non-linear dari service functionaly dan terdiri atas tiga komponen yaitu attractive,, propotional (one- dimensional) dan must be (Kano, et al. 1984; dalam Tjiptono \& Candra, 2016).

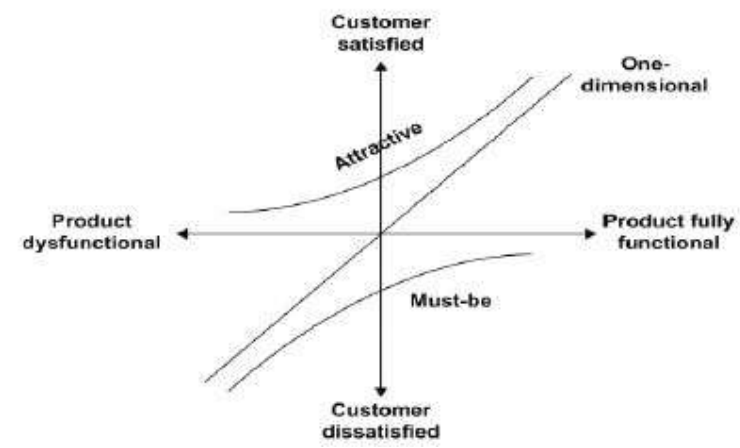

Gambar 2 Kano Model

Kano memberikan pemahaman bahwa semua atribut kepuasan pelanggan tidak sama, tidak hanya beberapa lebih penting bagi pelanggan, tetapi ada juga yang penting bagi pelanggan dengan cara yang berbeda dari yang lain (Cohen, 1995).

1. Must be, pelanggan akan tidak puas ketika atribut yang bersangkutan rendah. Namun kepuasan pelanggan tidak akan ada di atas kondisi netral.

2. One-dimensional, kepuasan pelanggan akan berhubungan secara linier terhadap perfoman atribut suatu produk.
3. Attractive, kepuasan pelanggan akan meningkat sangat tinggi secara linier bila ada peningkatan perfoman atribut suatu produk.

Terdapat tiga kategori kano selain dari kategori tersebut yaitu : Indifferent, reverse dan questionable, kategori tersebut tidak memberikan pengaruh pada kepuasan pelanggan sehingga kategori tersebut dapat diabaikan. Dari jawaban yang telah ditabulasikan menggunakan tabel evaluasi kano dapat ditentukan kategori kano dari atribut pertanyaannya dengan menggunakan Rumus Baulth Formula (Wijaya, 2018) :

Jika (one dimensional + attractive + must be) $>$ (indifferent + reverse + quaestionable) maka grade diperoleh dari yang paling maksimal dari (one dimensional, attractive, must be)

Jika (one dimensional + attractive + must be) $<$ (indifferent + reverse + quaestionable $)$ maka grade diperoleh dari yang paling maksimal dari (indifferent, reverse, quaestionable)

\section{F. Quality Function Deployment}

Quality Function Deployment ( $Q F D$ ) adalah metode untuk perencanaan dan pengembangan produk terstruktur yang memungkinkan tim pengembang untuk menentukan secara jelas keinginan dan kebutuhan pelanggan, dan kemudian mengevaluasi setiap produk yang diusulkan atau kemampuan layanan secara sistematis dalam memenuhi kebutuhan pelanggan (Cohen, 1995). QFD pertama kali dikembangkan di jepang pada Mitsubishi Kobe Shipyard tahun 1972 yang dipelopori oleh Yoji Akao pada tahun 1966. Perencanaan produk dengan menggunakan House of quality. 


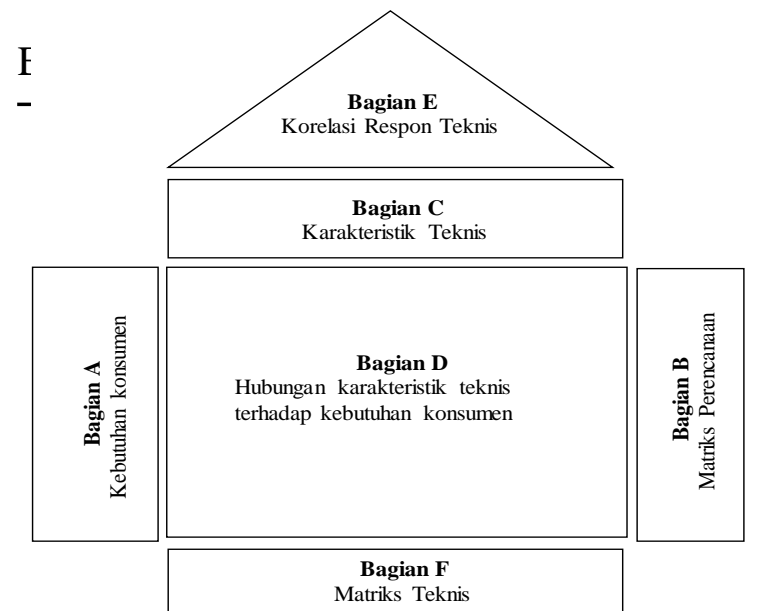

Gambar 3 House of Quality

Bagian A :

Merupakan kebutuhan konsumen (customer need). Pada fase ini kebutuhan pelanggan dikumpulkan dengan melalui interview atau wawancara dan kemudian dilakukan penyusunan secara hirarki.

Bagian B :

Pada bagian ini, akan dihitung sasaran atau tujuan produk yang didasarkan pada interpretasi tim terhadap data riset. Adapun bagian - bagian dari matriks perencanaan adalah sebagai berikut :

1. Tingkat kepentingan pelanggan (importance to customers)

2. Tingkat kepuasan pelanggan (Customer satisfaction perfomance)

3. Tingkat kepuasan pelanggan pesaing (Competitive satisfaction perfomance)

4. Goal/Target

5. Improvment ratio

6. Sales Point

7. Raw weight

8. Normalized raw weight

Bagian C :

Karakteristik teknis, berisikan persyaratan teknis untuk produk atau jasa baru yang akan dikembangkan.

Bagian D :

Berisikan kekuatan hubungan antara elemenelemen yang terdapat pada respon teknis (Bagian C) dan kebutuhan konsumen (bagian A).
Bagian E :

Merupakan hubungan atar respon teknis, matriks ini berbentuk menyerupai atap. Bagian ini menunjukan korelasi antara respon teknis yang satu dengan respon teknis yang lain yang terdapat pada bagian C (Wijaya, 2018).

Bagian F :

Pada bagian ini, akan ditunjukan tiga jenis data yaitu :Urutan tingkat kepentingan respon teknis "Priorities", Informasi hasil perbandingan kinerja produk "Competitive Benchmarks", Target yang ditentukan untuk respon teknis produk atau jasa yang baru atau yang akan dikembangkan.

\section{G. Pengintegrasian Servqual, Kano Model dan QFD}

Hubungan antara kepuasan pelanggan dan perfomance atribut diasumsikan berhubungan secara linier. Hal ini tidak sepenuhnya benar, asumsi ini dipatahkan oleh kano model, kano model mengklasifikasikan atribut menjadi tiga kategori yaitu one- dimensional yang mana kategori ini menjelaskan hubungan linear antara kepusasan pelanggan denga kinerja pelayanan, namun ada kategori attractive dan must be yang mana hubungannya tidak linear. Kano model tidak memberikan penilaian secara kuantitatif atau kualitatif atas kinerja kualitas atribut. Sebagaimana yang telah dapat diketahui kelemahan masing-masing metode antara servqual dan kano model, kelemahan tersebut dapat saling menutupi ketika metode ini digabungkan. Dalam pengintegrasian tersebut belum dapat secara sistematis dan operasional dilakukan karena servqual dan kano model tidak memberikan alat untuk upaya tersebut. Dari kelemahan tersebut di gabungkannya QFD, sebab QFD melalui HOQ akan menghubungkan atribut yang didapatkan dari model servqual yang terintegrasi dengan kano model dengan respon teknis perusahaan. Berikut ini merupakan prosedur dalam melakukan integrasi antara servqual, kano model dan QFD yaitu : 
1. Menentukan atribut pelayanan (data kualitatif dari model Servqual)

2. Membuat kuesioner model servqual dan kano model berdasarkan data atribut pelayanan yang didapatkan.

3. Pengumpulan dan pengolahan data kuantitatif model servqual dan kano model.

4. Menghitung gap score antara persepsi dan harapan pelanggan atas atribut layanan.

5. Menghitung Satisfaction score menggunakan rumus : Satisfaction score $=$ gap score $(Q) \mathrm{x}$ tingkat kepentingan

6. Mengklasifikasikan atribut layanan dengan kano model.

7. Titik integrasi dari tiga metode ini adalah menentukan nilai akhir dari Importance level of what pada QFD.

8. Menghitung Adjusted Importance (Importance level of what) menggunakan rumus : Satisfaction Score x nilai kano. Untuk nilai kano model, $\mathrm{A}=4, \mathrm{O}=2$ dan $\mathrm{M}=1$ ( Tan dan Pawitra 2001; dalam Kosasih et al., 2016)

\section{METODOLOGI PENELITIAN}

Metodologi penelitian merupakan gambaran penelitian secara keseluruhan sehingga dapat diketahui proses, metode, dan hasil yang diperoleh dari penelitian ini. Obyek dalam penelitian ini adalah kualitas pelayanan yang ada di klinik di instalasi rawat jalan RSUD Ibnu Sina.

Penelitian ini dimulai dengan survei pendahuluan untuk mengidentifikasi permasalahan yang terjadi kemudian dilakukan perumusan masalah dan penentuan tujuan penelitian setelah itu dilakukan studi literatur dan studi lapangan untuk mengetahui dengan jelas permasalahan yang terjadi dan langkah penyelasianya. Pada penelitian ini penyelesaian permasalahan menggunakan metode servqual, kano model dan QFD. Servqual mengidentifikasi atribut pelayanan dalam . Agar lebih jelas, kerangka berfikir dalam penelitian ini dapat dilihat pada gambar 4 .

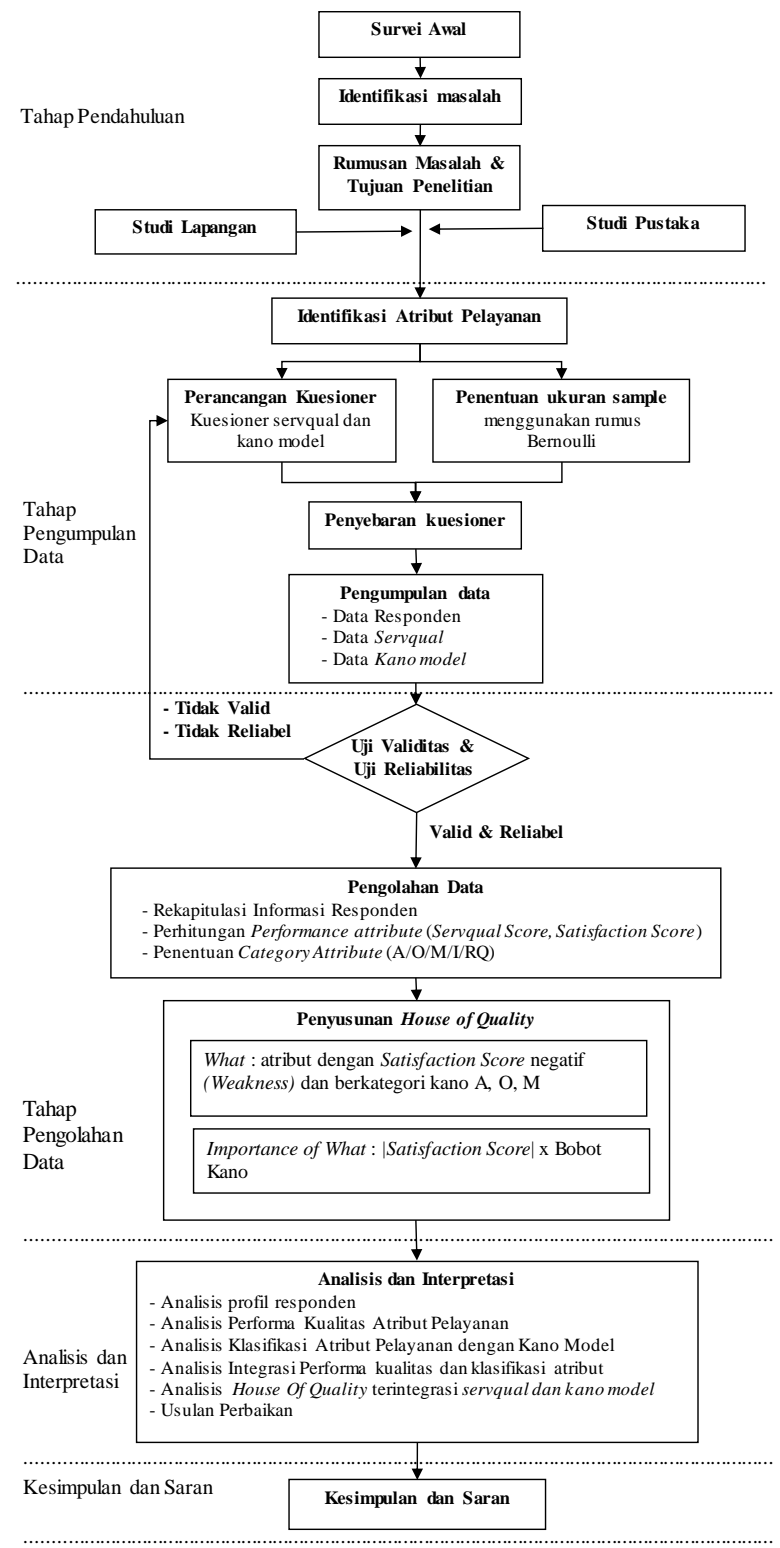

Gambar 4 Flowchart Penelitian

\section{HASIL DAN PEMBAHASAN}

Responden dalam penelitian ini adalah pasien dengan 152 orang yang terdiri dari 76 pasien klnik jantung dan 76 klink kandungan. Dari hasil kuesioner dapat diketahui bahwa pada klinik jantung responden sebagian besar $66,42 \%$ pasien adalah lulusan SMA. Dengan jenis kelamin Laki-Laki $67,11 \%$ dan Perempuan $32,89 \%$. Usia Pasien $48,68 \%$ masuk dalam kategori dewasa akhir. Dengan sebagian besar bekerja sebagai karyawan swasta. Pada klinik 
kandungan responden sebagian besar $74 \%$ pasien adalah lulusan SMA. Dengan jenis kelamin 100\% perempuan. Usia Pasien 44,74 \% masuk dalam kategori dewasa akhir. Dengan sebagian besar bekerja sebagai karyawan swasta

Dalam penelitian ini, teridentifikasi 21 atribut pelayanan yaitu :

Tabel 1 Atribut Pelayanan

\begin{tabular}{|c|c|c|}
\hline Peneliti & code & Atribut Pelayanan \\
\hline \multicolumn{3}{|r|}{ Tangibless } \\
\hline \multirow{4}{*}{$\begin{array}{l}\text { Sianturi \& Moses } \\
\text { (2011) }\end{array}$} & T.1 & Ruang Pelayanan yang bersih, indah dan nyaman \\
\hline & T.2 & \begin{tabular}{|l} 
Penerangan memadai dalam ruang pelayanan \\
\end{tabular} \\
\hline & T.3 & $\begin{array}{l}\text { Penampilan tenaga medis yang sopan, bersih dan } \\
\text { rapi disaat memberikan pelayanan }\end{array}$ \\
\hline & T.4 & Ketersediaan peralatan medis yang lengkap \\
\hline $\begin{array}{c}\text { Ekawati \& Triani } \\
\text { (2014) }\end{array}$ & T.5 & Memiliki ruang tunggu yang cukup dan nyaman \\
\hline \multicolumn{3}{|r|}{ Reliability } \\
\hline \multirow[b]{2}{*}{$\begin{array}{l}\text { Sianturi \& Moses } \\
\text { (2011) }\end{array}$} & R.1 & Jadwal Pelayanan yang tepat waktu \\
\hline & R.2 & $\begin{array}{l}\text { Biaya Pelayanan kesehatan yang diberikan pada } \\
\text { pasien terjangkau }\end{array}$ \\
\hline $\begin{array}{l}\text { Wahyuni \& wiwik } \\
(2015)\end{array}$ & R.3 & Lamanya waktu Pemeriksaan \\
\hline \multirow{2}{*}{ Maulana (2010) } & R.4 & Pemberian Pelayanan secara profesional dan benar \\
\hline & R.5 & \begin{tabular}{|l} 
Pemberian Pelayanan secara adil \\
\end{tabular} \\
\hline \multicolumn{3}{|r|}{ Responsiveness } \\
\hline \multirow{2}{*}{$\begin{array}{l}\text { Sianturi \& Moses } \\
\text { (2011) }\end{array}$} & Re.1 & $\begin{array}{l}\text { Daya tanggap tenaga medis terhadap keluhan } \\
\text { pasien }\end{array}$ \\
\hline & $\operatorname{Re} .2$ & Kemudahan dalam menemui tenaga medis \\
\hline \multirow[b]{2}{*}{$\begin{array}{l}\text { Wahyuni \& wiwik } \\
\text { (2015) }\end{array}$} & $\operatorname{Re} .3$ & $\begin{array}{l}\text { Kemampuan dan kecekatan tenaga medis dalam } \\
\text { menanggapi keluhan pasien }\end{array}$ \\
\hline & Re.4 & $\begin{array}{l}\text { Kemampuan tenaga medis dalam menjelaskan hasil } \\
\text { pemeriksaan }\end{array}$ \\
\hline \multicolumn{3}{|r|}{ Asqurance } \\
\hline \multirow{2}{*}{$\begin{array}{l}\text { Wahyuni \& wiwik } \\
(2015)\end{array}$} & A.1 & Keramahan tenaga medis dalam melayani pasien \\
\hline & A.2 & Kejelasan petugas dalam memberikan informasi \\
\hline Maulana (2010) & A.3 & $\begin{array}{l}\text { Sikap tenaga medis dalam membangkitkan moral } \\
\text { pasien }\end{array}$ \\
\hline \multicolumn{3}{|r|}{ Emphaty } \\
\hline \multirow{2}{*}{ Maulana (2010) } & E.1 & Kejelasan Informasi pelayanan \\
\hline & E.2 & Sarana Untuk mengetahui keluhan dan saran pasien \\
\hline $\begin{array}{c}\text { Sianturi \& Moses } \\
\text { (2011) }\end{array}$ & E.3 & Kemudahan pasien dalam mendapatkan informasi \\
\hline $\begin{array}{l}\text { Wahyuni \& wiwik } \\
\text { (2015) }\end{array}$ & E.4 & $\begin{array}{l}\text { Kesabaran tenaga medis dalam mendengarkan } \\
\text { keluhan pasien }\end{array}$ \\
\hline
\end{tabular}

\section{A. Skor Servqual}

Skor Servqual adalah skor kesenjangan antara persepsi dan harapan dari pelanggan. dalam penelitian ini, teridentifikasi 21 atribut pelayanan dengan hasil perhitungan gap score pada tabel 2 dan tabel 3 .
Tabel 2 Gap score klinik jantung

\begin{tabular}{|c|c|c|c|c|}
\hline No & Atribut Pelayanan & $\begin{array}{c}\text { Nilai } \\
\text { Harspan }\end{array}$ & $\begin{array}{c}\text { Nilai } \\
\text { Persepsi }\end{array}$ & $\begin{array}{l}\text { GAP } \\
\text { Score }\end{array}$ \\
\hline 1 & $\begin{array}{l}\text { Ruang Pelayanan yang bersih, indah dan } \\
\text { nyaman }\end{array}$ & 4,32 & 4,55 & 0,24 \\
\hline 2 & Penerangan memadai dalam ruang pelayanan & 4,25 & 3,66 & $-0,59$ \\
\hline 3 & $\begin{array}{l}\text { Penampilan tenaga medis yang sopan, bersih } \\
\text { dan rapi disaat memberikan pelayanan }\end{array}$ & 4,28 & 4,32 & 0,04 \\
\hline 4 & Ketergediaan peralatan medis yang lengkap & 4,54 & 4,55 & 0,01 \\
\hline 5 & $\begin{array}{l}\text { Memiliki ruang tunggu yang culkup dan } \\
\text { nyaman }\end{array}$ & 4,43 & 3,49 & $-0,95$ \\
\hline 6 & Jadwal Pelayanan yang tepat wakttu & 4,33 & 3,32 & $-1,01$ \\
\hline 7 & $\begin{array}{l}\text { Biaya Pelayanan kesehatan yang diberikan } \\
\text { pada pasien terjangkau }\end{array}$ & 4,14 & 3,37 & $-0,78$ \\
\hline 8 & Lamanya waktu Pemeriksaan & 4,36 & 3,54 & $-0,82$ \\
\hline 9 & $\begin{array}{l}\text { Pemberian Pelayanan secara profesional dan } \\
\text { benar }\end{array}$ & 4,55 & 3,74 & $-0,82$ \\
\hline 10 & Pemberian Pelayanan secara adil & 4,50 & 3,58 & $-0,92$ \\
\hline 11 & $\begin{array}{l}\text { Daya Tanggap Tenaga Medis terhadap } \\
\text { keluhan pasien }\end{array}$ & 4,36 & 3,37 & $-0,99$ \\
\hline 12 & Kemudahan dalam menemui tenaga medis & 4,36 & 3,22 & $-1,13$ \\
\hline 13 & $\begin{array}{l}\text { Kemampuan dan kecekatan tenaga medis } \\
\text { dalam menanggapi keluhan pasien }\end{array}$ & 4,24 & 3,11 & $-1,13$ \\
\hline 14 & $\begin{array}{l}\text { Kemampuan tenaga medis dalam } \\
\text { menjelaskan hasil pemeriksan keluhan }\end{array}$ & 4,41 & 3,42 & $-0,99$ \\
\hline 15 & $\begin{array}{l}\text { Keramahan tenaga medis dalam melayani } \\
\text { pasien }\end{array}$ & 4,38 & 3,59 & $-0,79$ \\
\hline 16 & $\begin{array}{l}\text { Kejelasan petugas dalam memberikan } \\
\text { informasi }\end{array}$ & 4,28 & 3,58 & $-0,70$ \\
\hline 17 & $\begin{array}{l}\text { Sikap tenaga medis dalam membangkitcam } \\
\text { moral pasien }\end{array}$ & 4,39 & 4,39 & 0,00 \\
\hline 18 & Kejelasan Informasi pelayanan & 4,37 & 3,71 & $-0,66$ \\
\hline 19 & $\begin{array}{l}\text { Sarana Untuk mengetahui keluhan dan saram } \\
\text { pasien }\end{array}$ & 4,29 & 3,37 & $-0,92$ \\
\hline 20 & $\begin{array}{l}\text { Kemudahan pasien dalam mendapatkan } \\
\text { informasi }\end{array}$ & 4,37 & 3,24 & $-1,13$ \\
\hline 21 & $\begin{array}{l}\text { Kesabaran tenaga medis dalam } \\
\text { mendengarkan keluhan pasien }\end{array}$ & 4,41 & 3,43 & $-0,97$ \\
\hline
\end{tabular}

Tabel 4 Gap score klinik kandungan

\begin{tabular}{|c|c|c|c|c|}
\hline No & Atribut Pelayanan & \begin{tabular}{|c|} 
Nilai \\
Harapan
\end{tabular} & $\begin{array}{c}\text { Nilai } \\
\text { Persepai }\end{array}$ & $\begin{array}{l}\text { GAP } \\
\text { Score }\end{array}$ \\
\hline 1 & $\begin{array}{l}\text { Ruang Pelayanan yang bersih, indah dan } \\
\text { nyaman }\end{array}$ & 4,46 & 4,54 & 0,08 \\
\hline 2 & Pererangan memadai dalam ruang pelayanan & 4,42 & 4,22 & $-0,20$ \\
\hline 3 & $\begin{array}{l}\text { Penampilan tenaga medis yang sopan, bersib } \\
\text { dan rapi diseat memberikan pelayanan }\end{array}$ & 4,38 & 4,43 & 0,05 \\
\hline 4 & Ketersediaan peralatan medis yang lengkap & 4,30 & 4,33 & 0,03 \\
\hline 5 & $\begin{array}{l}\text { Memiliki ruang tunggu yang cukup dan } \\
\text { nyaman }\end{array}$ & 4,50 & 3,87 & $-0,63$ \\
\hline 6 & Jadwal Pelayanan yang tepat wabtu & 4,45 & 3,78 & $-0,67$ \\
\hline 7 & $\begin{array}{l}\text { Biaya Pelayanan kesehatan yang diberikan } \\
\text { pada pasien terjangkau }\end{array}$ & 4,28 & 3,61 & $-0,67$ \\
\hline 8 & Lamanya waktu Pemeriksaan & 4,49 & 4,00 & $-0,49$ \\
\hline 9 & $\begin{array}{l}\text { Pemberian Pelayanan secara profesional dan } \\
\text { benar }\end{array}$ & 4,36 & 4,41 & 0,05 \\
\hline 10 & Pemberian Pelayanan secara adil & 4,33 & 3,76 & $-0,57$ \\
\hline 11 & $\begin{array}{l}\text { Daya Tanggap Tenaga Medis terhadap } \\
\text { keluhan pasien }\end{array}$ & 4,46 & 3,49 & $-0,97$ \\
\hline 12 & Kemudahan dalam menemui tenaga media & 4,41 & 3,68 & $-0,72$ \\
\hline 13 & $\begin{array}{l}\text { Kemampuan dan kecekatan tenaga medis } \\
\text { dalam menanggapi keluhan pasien }\end{array}$ & 4,38 & 3,80 & $-0,58$ \\
\hline 14 & $\begin{array}{l}\text { Kemampuan tenaga medis dalam } \\
\text { menjelaskan hasil pemeriksan keluhan }\end{array}$ & 4,34 & 3,67 & $-0,67$ \\
\hline 15 & $\begin{array}{l}\text { Keramahan tenaga medis dalam melayani } \\
\text { pasien }\end{array}$ & 4,32 & 4,32 & 0,00 \\
\hline 16 & $\begin{array}{l}\text { Kejelasan petugas dalam memberikan } \\
\text { informasi }\end{array}$ & 4,37 & 3,84 & $-0,53$ \\
\hline 17 & $\begin{array}{l}\text { Sikap tenaga medis dalam membangkitkan } \\
\text { moral pasien }\end{array}$ & 4,30 & 4,36 & 0,05 \\
\hline 18 & Kejelasan Informasi pelayanan & 4,34 & 3,82 & $-0,53$ \\
\hline 19 & $\begin{array}{l}\text { Sarana Untuk mengetahui keluhan dan saran } \\
\text { pasien }\end{array}$ & 4,30 & 3,83 & $-0,47$ \\
\hline 20 & $\begin{array}{l}\text { Kemudahan pasien dalam mendappatkan } \\
\text { informasi }\end{array}$ & 4,41 & 3,97 & $-0,43$ \\
\hline 21 & $\begin{array}{l}\text { Kesabaran tenaga medis dalam } \\
\text { mendengarkan keluban pasien }\end{array}$ & 4,46 & 4,49 & 0,03 \\
\hline
\end{tabular}




\section{B. Customer Satisfaction Score}

Dilakukan perhitungan skor kepuasan pelanggan (Customer Satisfaction Score). Yang nantinya akan diintegrasikan dengan kano model untuk menentukan Importance of What. Adapun hasil dari perhitungan skor kepuasan pelanggan adalah sebagai berikut.

Tabel 5 skor kepuasan klinik kandungan

\begin{tabular}{|c|c|c|c|c|}
\hline $\mathrm{N} 2$ & Shing & Gọpoorr: & Reperingun & CSS \\
\hline 1 & 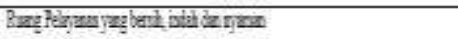 & C & 49 & 8,55 \\
\hline 2 & 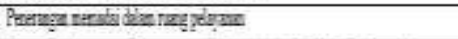 & 4 & 43 & 4,45 \\
\hline 3 & 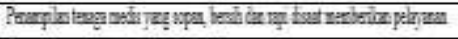 & WE & 439 & 29 \\
\hline 4 & 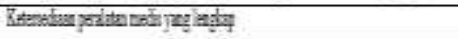 & L & $4 \pi$ & 0,12 \\
\hline 5 & 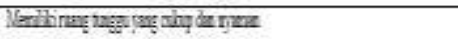 & $45:$ & tho & .28 \\
\hline 5 & 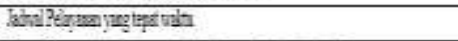 & 45 & 4 ISI & $.3,6$ \\
\hline 7 & 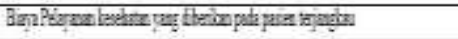 & $\frac{15}{425}$ & 46 & 249 \\
\hline 1 & 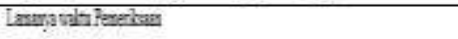 & 49 & 43 & 317 \\
\hline 9 & 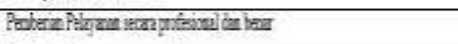 & W5 & 47 & 23 \\
\hline in & Patera Plyan seanati & $-4 \div$ & 145 & 245 \\
\hline II & 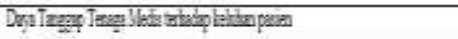 & 49 & 40 & 45 \\
\hline 12 & 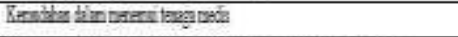 & 47 & 45 & 315 \\
\hline 13 & 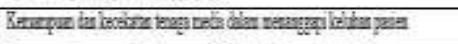 & 42 & 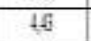 & 264 \\
\hline H & 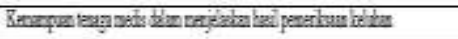 & 4,5 & 48 & 291 \\
\hline 5 & 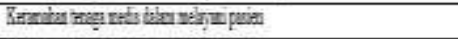 & 50 & 45 & 0,6 \\
\hline 16 & 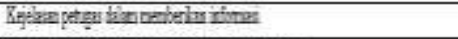 & 459 & 4.6 & .235 \\
\hline 17 & 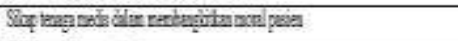 & W & 433 & $2 y$ \\
\hline I & 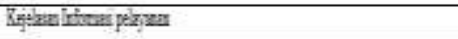 & 45 & 437 & 213 \\
\hline 19 & 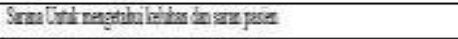 & $4 \sqrt{4}$ & 451 & 207 \\
\hline 2) & Benuthar pra binsondy thin ufreai & 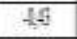 & 45 & 1,96 \\
\hline 21 & 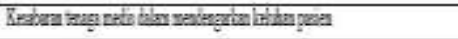 & EF & 48 & 2,12 \\
\hline
\end{tabular}

\section{Klasifikasi Atribut Kano Model}

Berdasarkan data yang didapatkan dalam kuesioner kano yang disebarkan yaitu pertanyaan-pertanyaan functional dan dysfunctional, untuk mengetahui seberapa besar pengaruh dari atribut pelayanan terhadap kepusana pelanggan. Klasifikasi dari model kano akan ditetapkan berdasarkan bantuan Kano Evaluaton Model. Dan didapatkan hasil sebagai berikut :
Tabel 6 kategori kano klinik jantung

\begin{tabular}{|l|l|c|}
\hline No & \multicolumn{1}{|c|}{ Atribut } & $\begin{array}{c}\text { Kategori } \\
\text { Kano }\end{array}$ \\
\hline 1 & Ruang Pelayanan yang bersih, indah dan nyaman & $\mathrm{O}$ \\
\hline 2 & Penerangan memadai dalam ruang pelayanan & $\mathrm{M}$ \\
\hline 3 & $\begin{array}{l}\text { Penampilan tenaga medis yang sopan, bersih dan rapi disaat } \\
\text { memberikan pelayanan }\end{array}$ & $\mathrm{M}$ \\
\hline 4 & Ketersediaan peralatan medis yang lengkap & $\mathrm{A}$ \\
\hline 5 & Memiliki ruang tunggu yang cukup dan nyaman & $\mathrm{O}$ \\
\hline 6 & Jadwal Pelayanan yang tepat waktu & $\mathrm{O}$ \\
\hline 7 & Biaya Pelayanan kesehatan yang diberikan pada pasien terjangkau & $\mathrm{M}$ \\
\hline 8 & Lamanya waktu Pemeriksaan & $\mathrm{M}$ \\
\hline 9 & Pemberian Pelayanan secara profesional dan benar & $\mathrm{A}$ \\
\hline 10 & Pemberian Pelayanan secara adil & $\mathrm{O}$ \\
\hline 11 & Daya Tanggap Tenaga Medis terhadap keluhan pasien & $\mathrm{O}$ \\
\hline 12 & Kemudahan dalam menemui tenaga medis & $\mathrm{O}$ \\
\hline 13 & $\begin{array}{l}\text { Kemampuan dan kecekatan tenaga medis dalam menanggapi } \\
\text { keluhan pasien }\end{array}$ & $\mathrm{M}$ \\
\hline 14 & $\begin{array}{l}\text { Kemampuan tenaga medis dalam menjelaskan hasil pemeriksaan } \\
\text { keluhan }\end{array}$ & $\mathrm{O}$ \\
\hline 15 & Keramahan tenaga medis dalam melayani pasien & $\mathrm{O}$ \\
\hline 16 & Kejelasan petugas dalam memberikan informasi & $\mathrm{M}$ \\
\hline 17 & Sikap tenaga medis dalam membangkitkan moral pasien & $\mathrm{O}$ \\
\hline 18 & Kejelasan Informasi pelayanan & $\mathrm{M}$ \\
\hline 19 & Sarana Untuk mengetahui keluhan dan saran pasien & $\mathrm{A}$ \\
\hline 20 & Kemudahan pasien dalam mendapatkan informasi & $\mathrm{M}$ \\
\hline 21 & Kesabaran tenaga medis dalam mendengarkan keluhan pasien & $\mathrm{O}$ \\
\hline
\end{tabular}

Tabel 7 kategori kano klinik kandungan

\begin{tabular}{|l|l|c|}
\hline No & \multicolumn{1}{|c|}{ Atribut } & $\begin{array}{c}\text { Kategori } \\
\text { Kano }\end{array}$ \\
\hline 1 & Ruang Pelayanan yang bersih, indah dan nyaman & $\mathrm{O}$ \\
\hline 2 & Penerangan memadai dalam ruang pelayanan & $\mathrm{A}$ \\
\hline 3 & $\begin{array}{l}\text { Penampilan tenaga medis yang sopan, bersih dan rapi disaat } \\
\text { memberikan pelayanan }\end{array}$ & $\mathrm{M}$ \\
\hline 4 & Ketersediaan peralatan medis yang lengkap & $\mathrm{A}$ \\
\hline 5 & Memiliki ruang tunggu yang cukup dan nyaman & $\mathrm{O}$ \\
\hline 6 & Jadwal Pelayanan yang tepat walktu & $\mathrm{O}$ \\
\hline 7 & Biaya Pelayanan kesehatan yang diberikan pada pasien terjangkau & $\mathrm{M}$ \\
\hline 8 & Lamanya waltu Pemeriksaan & $\mathrm{M}$ \\
\hline 9 & Pemberian Pelayanan secara profesional dan benar & $\mathrm{A}$ \\
\hline 10 & Pemberian Pelayanan secara adil & $\mathrm{O}$ \\
\hline 11 & Daya Tanggap Tenaga Medis terhadap keluhan pasien & $\mathrm{O}$ \\
\hline 12 & Kemudahan dalam menemui tenaga medis & $\mathrm{M}$ \\
\hline 13 & $\begin{array}{l}\text { Kemampuan dan kecekatan tenaga medis dalam menanggapi } \\
\text { keluhan pasien }\end{array}$ & $\mathrm{M}$ \\
\hline 14 & $\begin{array}{l}\text { Kemampuan tenaga medis dalam menjelaskan hasil pemeriksaan } \\
\text { keluhan }\end{array}$ & $\mathrm{O}$ \\
\hline 15 & Keramahan tenaga medis dalam melayani pasien & $\mathrm{A}$ \\
\hline 16 & Kejelasan petugas dalam memberikan informasi & $\mathrm{M}$ \\
\hline 17 & Sikap tenaga medis dalam membangkitkan moral pasien & $\mathrm{O}$ \\
\hline 18 & Kejelasan Informasi pelayanan & $\mathrm{M}$ \\
\hline 19 & Sarana Untuk mengetahui keluhan dan saran pasien & $\mathrm{A}$ \\
\hline 20 & Kemudahan pasien dalam mendapatkan informasi & $\mathrm{M}$ \\
\hline 21 & Kesabaran tenaga medis dalam mendengarkan keluhan pasien & $\mathrm{O}$ \\
\hline
\end{tabular}

\section{Integrasi servqual dan kano model}

Hasil dari penginterasian antara servqual dan kano model akan menutupi kekurangan dari masing masing metode. Kano model dapat menutupi kelemahan servqual yang mengasumsikan hubungan linear antara perfoman dari pelayanan dengan tingkat kepuasan pelanggan. Sedangkan metode servqual dapat mengidentifikasi kinerja dari atribut dari gap score dan dimensi yang ada. Penentuan keterangan Strenght berdasarkan pada gap score positif dan masuk dalam kategori kano 
$(\mathrm{A}, \mathrm{O}, \mathrm{M})$ dan penentuan keterangan Weakness berdasarkan pada gap score negatif dan masuk dalam kategori kano (A,O,M) (Farah, 2018).

\section{E. Penyusunan house of quality terintegrasi servqual dan kano model}

Atribut yang memiliki skor kepuasan negatif dan termasuk aktegori kano M (must be), A (attractive) dan $\mathrm{O}$ (one-dimensional) adalah atribut yang perlu dilakukan perbaikan berdasarkan pengintegrasian servqual dan kano model, didapatkan 17 atribut di klinik jantung dan 14 atribut di klinik kandungan.

\section{Penentuan importance level of what}

Importance level of What merupakan hasil dari integrasi servqual dan kano model yang dijadikan sebagai elemen penyusun HOQ untuk menentukan bobot dari kebutuhan pelanggan (Farah, 2018).:

Importance level of What $(I L W)=\mid$ Satisfaction Score| x Nilai Kano

Tabel 8 Importance level of what klinik jantung

\begin{tabular}{|c|l|c|c|c|c|}
\hline No & \multicolumn{1}{|c|}{ VOC } & |CSS| & Kano & $\begin{array}{c}\text { Kano } \\
\text { score }\end{array}$ & ILW \\
\hline 1 & Penerangan memadai dalam ruang pelayanan & 0,85 & $\mathrm{M}$ & 1 & 0,85 \\
\hline 2 & Memiliki ruang tunggu yang cukup dan nyaman & 4,21 & $\mathrm{O}$ & 2 & 8,42 \\
\hline 3 & Jadwal Pelayanan yang tepat waltu & 4,49 & $\mathrm{O}$ & 2 & 8,98 \\
\hline 4 & $\begin{array}{l}\text { Biaya Pelayanan kesehatan yang diberikan pada pasien } \\
\text { terjangkau }\end{array}$ & 3,31 & $\mathrm{M}$ & 1 & 3,31 \\
\hline 5 & Lamanya walku Pemeriksaan & 3,48 & $\mathrm{M}$ & 1 & 3,48 \\
\hline 6 & Pemberian Pelayanan secara profesional dan benar & 3,69 & $\mathrm{~A}$ & 4 & 14,76 \\
\hline 7 & Pemberian Pelayanan secara adil & 4,06 & $\mathrm{O}$ & 2 & 8,12 \\
\hline 8 & Daya Tanggap Tenaga Medis terhadap keluhan pasien & 4,39 & $\mathrm{O}$ & 2 & 8,78 \\
\hline 9 & Kemudahan dalam menemui tenaga medis & 4,93 & $\mathrm{O}$ & 2 & 9,86 \\
\hline 10 & $\begin{array}{l}\text { Kemampuan dan kecekatan tenaga medis dalam } \\
\text { menanggapi keluhan pasien }\end{array}$ & 5,03 & $\mathrm{M}$ & 1 & 5,03 \\
\hline 11 & $\begin{array}{l}\text { Kemampuan tenaga medis dalam menjelaskan hasil } \\
\text { pemeriksaan keluhan }\end{array}$ & 4,30 & $\mathrm{O}$ & 2 & 8,6 \\
\hline 12 & Keramahan tenaga medis dalam melayani pasien & 3,47 & $\mathrm{O}$ & 2 & 6,94 \\
\hline 13 & Kejelasan petugas dalam memberikan informasi & 3,05 & $\mathrm{M}$ & 1 & 3,05 \\
\hline 14 & Kejelasan Informasi pelayanan & 2,91 & $\mathrm{M}$ & 1 & 2,91 \\
\hline 15 & Sarana Untuk mengetahui keluhan dan saran pasien & 4,00 & $\mathrm{~A}$ & 4 & 16 \\
\hline 16 & Kemudahan pasien dalam mendapatkan informasi & 4,87 & $\mathrm{M}$ & 1 & 4,87 \\
\hline 17 & $\begin{array}{l}\text { Kesabaran tenaga medis dalam mendengarkan keluhan } \\
\text { pasien }\end{array}$ & 4,19 & $\mathrm{O}$ & 2 & 8,38 \\
\hline
\end{tabular}

Tabel 9 Importance level of what klinik kandungan

\begin{tabular}{|c|l|c|c|c|c|}
\hline No & \multicolumn{1}{|c|}{ VOC } & $\mid$ CSS & Kano & $\begin{array}{c}\text { Kano } \\
\text { score }\end{array}$ & ILW \\
\hline 1 & Penerangan memadai dalam ruang pelayanan & 0,85 & $\mathrm{~A}$ & 4 & 3,4 \\
\hline 2 & Memiliki ruang tunggu yang cukup dan nyaman & 2,82 & 0 & 2 & 5,64 \\
\hline 3 & Jadwal Pelayanan yang tepat waktu & 3,03 & $\mathrm{O}$ & 2 & 6,06 \\
\hline 4 & $\begin{array}{l}\text { Biaya Pelayanan kesehatan yang diberikan pada } \\
\text { pasien terjangkau }\end{array}$ & 2,99 & $\mathrm{M}$ & 1 & 2,99 \\
\hline 5 & Lamanya waktu Pemeriksaan & 2,17 & $\mathrm{M}$ & 1 & 2,17 \\
\hline 6 & Pemberian Pelayanan secara adil & 2,45 & $\mathrm{O}$ & 2 & 4,9 \\
\hline 7 & $\begin{array}{l}\text { Daya Tanggap Tenaga Medis terhadap keluhan } \\
\text { pasien }\end{array}$ & 4,32 & $\mathrm{O}$ & 2 & 8,64 \\
\hline 8 & Kemudahan dalam menemui tenaga medis & 3,26 & $\mathrm{M}$ & 1 & 3,26 \\
\hline 9 & $\begin{array}{l}\text { Kemampuan dan kecekatan tenaga medis dalam } \\
\text { menanggapi keluhan pasien }\end{array}$ & 2,64 & $\mathrm{M}$ & 1 & 2,64 \\
\hline 10 & $\begin{array}{l}\text { Kemampuan tenaga medis dalam menjelaskan } \\
\text { hasil pemeriksaan keluhan }\end{array}$ & 2,98 & $\mathrm{O}$ & 2 & 5,96 \\
\hline 11 & Kejelasan petugas dalam memberikan informasi & 2,35 & $\mathrm{M}$ & 1 & 2,35 \\
\hline 12 & Kejelasan Informasi pelayanan & 2,28 & $\mathrm{M}$ & 1 & 2,28 \\
\hline 13 & $\begin{array}{l}\text { Sarana Untuk mengetahui keluhan dan saran } \\
\text { pasien }\end{array}$ & 2,07 & $\mathrm{~A}$ & 4 & 8,28 \\
\hline 14 & Kemudahan pasien dalam mendapatkan informasi & 1,96 & $\mathrm{M}$ & 1 & 1,96 \\
\hline
\end{tabular}

\section{Respon Teknis}

Berdasarkan hasil dari FGD yang telah dilakukan dengan dua pegawai pembina tingkat I \&II di bidang pelayanan medik maka didapatkan hasil informasi tentang respon teknis sebagai berikut :

- Melakukan pelatihan dan pendidikan kepada tenaga medis

- Briefing orientasi kualitas kepada tenaga medis

- Program tenaga medis dan petugas teladan/terbaik

- Rehabilitasi fasilitas gudang dan peralatan pendukung

- Pemberian kotak saran dan aduan

- Perbaikan sistem informasi

- Mengadakan kegiatan informasi dan promosi

- Perbaikan sistem monitoring dan evaluasi kinerja

- Peningkatan kerjasama (Asuransi kesehatan)

3. Hubungan antar respon teknis

Relatioship matrix menunjukan hubungan antara kebutuhan pelanggan dengan respon teknis. Dalam menentukan hubungan tersebut dilakukan diskusi dengan dua orang pegawai bidang pelayanan medik. 
4. Arah pengembangan

Arah pengembangan dapat berupa arah pengembangan yang niak, tetap atau turun dan target dapat berupa angka kuantitatif ataupun gambaran kualitatif. Arah pengembangan ini didapat dari FGD dengan dua pegawai bidang pelayanan medik. Semua respon teknis dalam penelitian ini memiliki target pengembangan naik (more is better).

\section{Bobot respon teknis}

Bobot respon teknis digunakan untuk menentukan respon teknis mana yang menjadi prioritas untuk memenuhi kebutuhan kebutuhan pelanggan. Perhitungan nilai kepentingan absolute (Absolute Importance) atau Importance of how dan nilai kepentingan relatif (Relative Importance) persentase Importance of how yang digunakan digunakan adalah sebagai berikut (Supengat \& Kustiani, 2016):

* Importance of how $=\Sigma$ (Importance of what $\mathrm{x}$ bobot keterhubungan)

* Persentase Importance of how = Importance of how / $\Sigma$ Kepentingan Absolut

Tabel 10 Bobot respon teknis

\begin{tabular}{|c|c|c|c|c|}
\hline No & Respon Tokins & Bobot & $\begin{array}{c}\% \\
\text { Bobot }\end{array}$ & $\begin{array}{l}\text { Urutan } \\
\text { Pricotias }\end{array}$ \\
\hline 1. & $\begin{array}{l}\text { Meledukan peiatihas dan penditican kegada ternags } \\
\text { medis }\end{array}$ & 730,14 & $31 \%$ & 1 \\
\hline 2 & Brefing crierkan kualitas kepada imata mola & 430,55 & $15 \%$ & 2 \\
\hline 3 & Progranu teniga medis dan petugas seladan terbaik & 301,26 & $15 \%$ & 5 \\
\hline 4. & 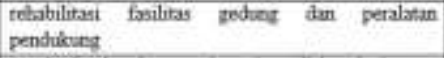 & 164,79 & $7 \%$ & 6 \\
\hline 5. & $\begin{array}{l}\text { Penberian kocak saran das afivan di invalan rawat } \\
\text { jalan }\end{array}$ & 232,58 & $10 \%$ & 4 \\
\hline 5 & Perbatkan ssiem informast & 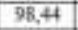 & $f^{\circ}$ & 8 \\
\hline 2. & Mengadahat kegiatan informast des promos & 115,8 & $3 \%$ & 7 \\
\hline 8. & Petbukan sistem moevionng dan evalvosi kinerja & 200,91 & $8 \%$ & 5 \\
\hline 9. & Frningkatan kefjasamu (Avurani kenchation) & 56.7 & 296 & क \\
\hline
\end{tabular}

\section{Improvement Ratio}

Improvement ratio merupakan suatu ukuran relatif yang digunakan untuk menunjukan perbandingan posisi penyedia jasa saat ini dengan harapan kosumen (Farah, 2018). Nilai ini dapat dihitung dengan rumus : Improvement ratio $=$ Tingkat harapan/Tingkat
Tabel 11 Improvement Ratio

\begin{tabular}{|c|c|c|c|c|}
\hline $\mathrm{su}$ & Antat Fuepuas & Kinerie & nespes & $\ln x$ \\
\hline \multicolumn{5}{|c|}{ carmes } \\
\hline $\mathrm{I}$ & 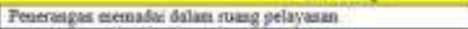 & 1,0 & 424 & 1.11 \\
\hline I & 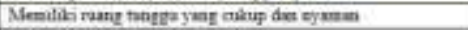 & Iof & की & 5 \\
\hline $\mathbf{T}$ & 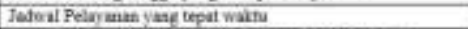 & 2112 & 45 & 1,0 \\
\hline 7 & 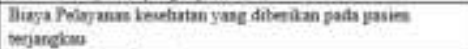 & का & 6 & 1,20 \\
\hline 1 & Lantatya walts Pematriasati & 34 & 45 & 1,5 \\
\hline T & 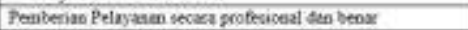 & $x^{4}$ & 498 & ta2 \\
\hline & 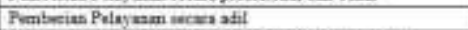 & 15 & 60 & $17 \pi$ \\
\hline$r$ & 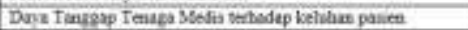 & क्ञ? & 40 & 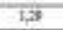 \\
\hline 2 & 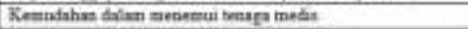 & कम & 496 & 138 \\
\hline$\pi$ & 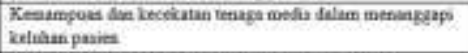 & 2,11 & 420 & tat \\
\hline II & 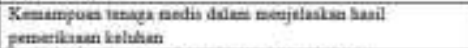 & 30 & ais & 1,3 \\
\hline HII & 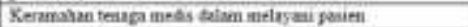 & 2.5 & 490 & It \\
\hline III & 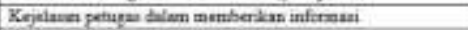 & एII & $42 \pi$ & La \\
\hline I & Keplaser luforeasi pelayaten & 27 & 49 & t,11 \\
\hline in & 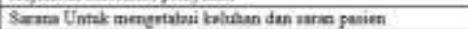 & कर & $4 \$$ & ET \\
\hline$\pi$ & 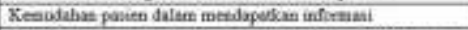 & 204 & का & $1+5$ \\
\hline 31 & 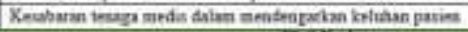 & $(40)$ & ai & 13 \\
\hline \multicolumn{5}{|c|}{ 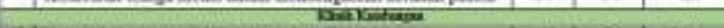 } \\
\hline II & 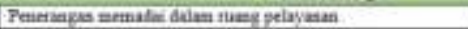 & xII & 460 & 100 \\
\hline ए" & 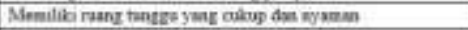 & प्र & 20 & Lif \\
\hline य & 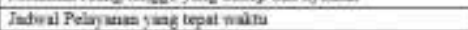 & 17 & tet & Lil \\
\hline (IT) & 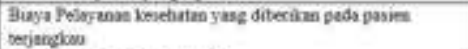 & 3ai & $a$ & 2.18 \\
\hline II & 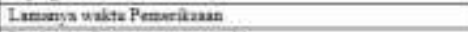 & $4 \infty$ & 40 & 0,12 \\
\hline II & Penterim Pelayranan secere adil & का & 49 & 1,15 \\
\hline 3 & 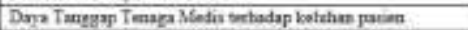 & त्र & (4) & मक्त \\
\hline$I I$ & 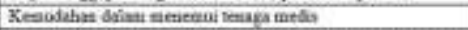 & $2 \mathrm{se}$ & 401 & thi \\
\hline$\pi$ & 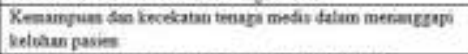 & a* & 1) 34 & 7,15 \\
\hline${ }^{2}$ & 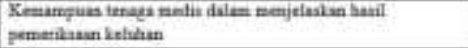 & $2 \pi$ & 434 & 1,il \\
\hline III & 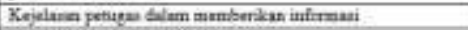 & II & at & 1.14 \\
\hline 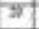 & Kejelaian Infreasai selayaten & iti & 44 & 1,112 \\
\hline D & 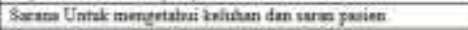 & IF & 90 & IIA \\
\hline II & 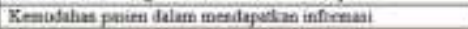 & 40 & 4ता & क्ष \\
\hline
\end{tabular}

\section{Sales Point}

Nilai ini mencerminkan seberapa menguntungkan kebutuhan pelanggan tersebut berdampak pada perusahaan jika kebutuhan itu dipenuhi. Dalam pengelomokan sales pont ini dibagi menjadi tiga kategori yaitu :

1. Sales pont 1,0 jika tidak menguntungkan bagi perusahaan

2. Sales point 1,2 jika cukup menguntungkan bagi perusahaan.

3. Sales point 1,5 jika sangat menguntungkan bagi perusahaan

Berikut merupakan sales point dari tiap atribut untuk kedua klinik yang atributnya mengalami penurunan kepuasan pelayanan yang dapat dilit pada Tabel 9 
Tabel 12 Sales Point

\begin{tabular}{|c|c|c|}
\hline No & VOC & $\begin{array}{l}\text { Sales } \\
\text { Point }\end{array}$ \\
\hline$t$ & Penerangas termade Salim raang pelsyanis & 1,20 \\
\hline 2 & Memilaki fang tuaggu yang cukup dian syaman & 1,50 \\
\hline 3 & Jadual Pelay oman yasg tepat wakts & 1,50 \\
\hline 4 & Binya Pelayana kesebatan yang điberika pada pasien terjangkau & 1,50 \\
\hline 5 & Lamanga wakts Pemeriksan & 1,50 \\
\hline 6 & Pemberian Pelay youn sciara profesional dan benar & 1,20 \\
\hline 7 & Penterian Pelayesin secara adil & 1,20 \\
\hline 8 & 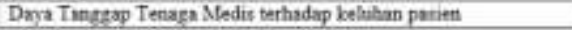 & 1,50 \\
\hline 9 & Kempodnhan dalam menernai ienage media & 1,00 \\
\hline 10 & 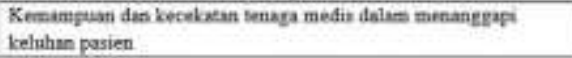 & 1,50 \\
\hline II & $\begin{array}{l}\text { Kenampown tensaga medì dalam menjelaskan hasil pemerikasen } \\
\text { ketuhas }\end{array}$ & 1,50 \\
\hline 12 & Kenamilan tenags meda dalam melayam parien & 1,50 \\
\hline 13 & Kejetasie petugas delatt menterikan ieformas & 1,50 \\
\hline 14 & Kejelasias Informasi pelayman & 1,20 \\
\hline 15 & Sarana Uatuli: mengetahiai kelahan dan sarne pasien & 1,50 \\
\hline 16 & Reswadahan pasien dalam mendapascan intornazi & 1,50 \\
\hline 17 & Kesabaran tenaga medis dalam mendeatgarkan ketuhan pasien & 1,50 \\
\hline
\end{tabular}

8. Raw Weight dan Normalized Raw Weight

Setelah diketahui nilai Importance level of what, improvement ratio dan sales point maka dilakukan perhitungan raw weight dan normalized raw weight yang menunjukan seberapa besar perbaikan pelayanan yang dilakukan oleh klinik.

Raw weight $=$ importance to customers $x$ improvement ratio $\mathrm{x}$ sales point

Hasil dari perhitungan raw weight dan normailized raw weight dapat dilihat pada tabel 13

Tabel 13 Raw Weight dan Normalized Raw Weight klinik jantung

\begin{tabular}{|c|c|c|c|}
\hline $\mathbf{N}_{\mathbf{0}}$ & roc & $\begin{array}{l}\text { Rew } \\
\text { Weight }\end{array}$ & $\begin{array}{c}\text { Narnabibsed row } \\
\text { nnight }\end{array}$ \\
\hline 1 & 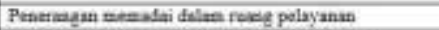 & 1,2 & 0,004 \\
\hline 2 & 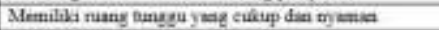 & 16,0 & 0,050 \\
\hline 3 & Jaswal Pelay mata yang topat waltu & 17,6 & 0,055 \\
\hline 4 & 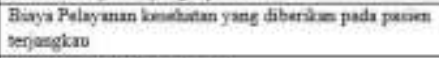 & 6,1 & 0,010 \\
\hline 3 & Lamanya wiktu Pernerikasum & 6,4 & 0,020 \\
\hline 6 & 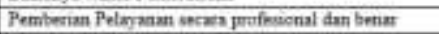 & 26,9 & 0,04 \\
\hline 7 & Penterimu Pelagannen secars add & 12,2 & 0,031 \\
\hline 8 & 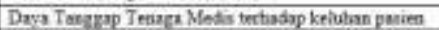 & 170 & 0.053 \\
\hline 9 & 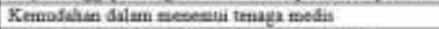 & 13,4 & 0,041 \\
\hline 10 & 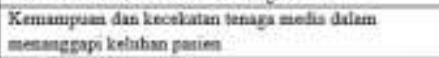 & 10,3 & 0,032 \\
\hline 11 & 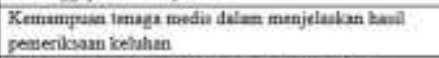 & 16,5 & 0,052 \\
\hline 12 & Keramalhas tenaga wedes bolam melay we pasien & 12,7 & 0.099 \\
\hline 13 & Kejelasan peougas dolam mentibenkine informzai & 5,5 & 0,017 \\
\hline 14 & Kejelasan Informasi pelayanan & 4,1 & 0,013 \\
\hline 15 & 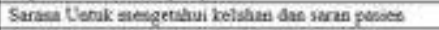 & 30,6 & 0.091 \\
\hline 16 & 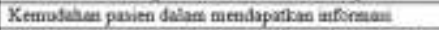 & 9,9 & 0,091 \\
\hline 17 & 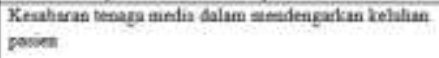 & 16,2 & 0.050 \\
\hline
\end{tabular}

Tabel 14 Raw Weight dan Normalized Raw Weight

\begin{tabular}{|c|c|c|c|}
\hline No & noc & $\begin{array}{l}\text { Rew } \\
\text { Wegphet }\end{array}$ & $\begin{array}{c}\text { Narmidited rem } \\
\text { weight }\end{array}$ \\
\hline 1 & 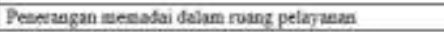 & 4,3 & $0,01 \frac{1}{3}$ \\
\hline$\frac{2}{2}$ & Memilks suang tanzzo yasg culvop dan ayama & 9,8 & 0,031 \\
\hline 3 & 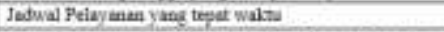 & 10,7 & 0,033 \\
\hline 4 & 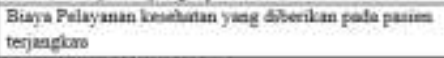 & 5,3 & 0,016 \\
\hline 5 & Lamanya waktu Perneriksas & 3,7 & 0,511 \\
\hline 6 & Penberian Pelayanan secarn atif & 6,8 & 0,021 \\
\hline$T$ & 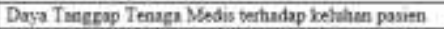 & 16,6 & 0,051 \\
\hline 1 & Remiodzhen dalan menensis tenaga medis & 3,9 & 0,012 \\
\hline 9 & 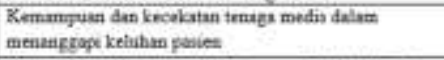 & 4,6 & 0,054 \\
\hline 10 & 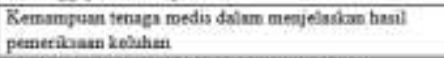 & 10,6 & 0,693 \\
\hline II & 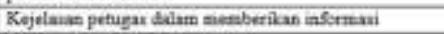 & 4,0 & 0,013 \\
\hline 12 & Kejelosan isformasi pelaysuan & 3,1 & 0,010 \\
\hline 13 & 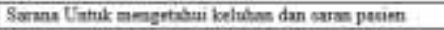 & 13,5 & 0,042 \\
\hline 19 & Kempdahan pasien dolam mendapadtan informai & 29 & 0,009 \\
\hline
\end{tabular}

9. Hubungan Antar respon teknis

Hubungan antar respon teknis adalah hubungan saling keterkaitan. Penentuan hubungan diperoleh dari FGD dengan dua pegawai bidang pelayanan medik. Terdapat 5 tingkatan pengaruh/hubungan yaitu :

$(\sqrt{ })$ pengaruh positif kuat

$(\sqrt{ })$ pengaruh positif sedang

( ) tidak ada hubungan

( $\mathrm{x}$ ) pengaruh negatif sedang

( $x x$ ) pengaruh negatif kuat

Hubungan respon teknis dapat dilihat pada Gambar 6

Gambar 5 Hubungan Antar Respon Teknis

\section{KESIMPULAN DAN SARAN}

\section{A. Kesimpulan}

Dari penelitian yang telah dilakukan, didapatkan kesimpulan sebagai berikut : 
1. Pada klinik jantung dari 21 atribut pelayanan yang teridentifikasi terdapat 4 atribut pelayanan yang melebihi harapan dari pasien. Atribut itu adalah :

a) Ruang pelayanan yang bersih, indah dan nyaman dengan gap score $(0,24)$

b) Penampilan tenaga medis yang sopan, bersih dan rapi disaat memberikan pelayanan dengan gap score $(0,04)$

c) Ketersediaan peralatan medis yang lengkap dengan gap score $(0,01)$

d) Sikap tenaga medis dalam membangkitkan moral pasien dengan gap score $(0,00)$

Pada klinik kandungan dari 21 atribut pelayanan yang teridentifikasi terdapat 7 atribut pelayanan yang melebihi harapan pasien, atribut tersebut adalah :

a) Ruang pelayanan yang bersih, indah dan nyaman dengan gap score $(0,08)$

b) Penampilan tenaga medis yang sopan, bersih dan rapi disaat memberikan pelayanan dengan gap score $(0,05)$

c) Ketersediaan peralatan medis yang lengkap dengan gap score $(0,03)$

d) Pemberian pelayanan secara profesional dan benar dengan gap score $(0,05)$

e) Keramahan tenaga medis dalam melayani pasien dengan gap score $(0,00)$

f) Sikap tenaga medis yang membangkitkan moral pasien dengan gap score $(0,05)$

g) Kesabaran tenaga medis dalam mendengarkan keluhan pasien dengan gap score $(0,03)$.

2. Berdasarkan perfoma dan klasifikasi atribut yang harus dipertahankan, diperbaiki dan ditingkatkan kualitasnya dapat dikategorikan sebagai berikut

a) Tindakan terhadap atribut pelayanan di klinik jantung

Berdasarkan integrasi servqual dan kano model didapatkan hasil bahwa atribut yang harus dilakukan pengembangan adalah : Pemberian Pelayanan secara profesional dan benar, sarana Untuk mengetahui keluhan dan saran pasien

Atribut yang harus dilakukan perbaikan dan peningkatan adalah :

* Memiliki ruang tunggu yang cukup dan nyaman

* Jadwal Pelayanan yang tepat waktu

* Pemberian Pelayanan secara adil

* Daya Tanggap Tenaga Medis terhadap keluhan pasien

* Kemudahan dalam menemui tenaga medis

* Kemampuan tenaga medis dalam menjelaskan hasil pemeriksaan

* Keramahan tenaga medis dalam melayani pasien

* Kesabaran tenaga medis dalam mendengarkan keluhan pasien

Atribut yang harus dilakukan perbaikan adalah :

* Penerangan memadai dalam ruang pelayanan

* Biaya Pelayanan kesehatan yang diberikan pada pasien terjangkau

* Lamanya waktu Pemeriksaan

- Kemampuan dan kecekatan tenaga medis dalam menanggapi keluhan pasien

* Kejelasan petugas dalam memberikan informasi

* Kejelasan Informasi pelayanan

* Kemudahan pasien dalam mendapatkan informasi

b) Tindakan terhadap atribut pelayanan di klinik kandungan.

Berdasarkan integrasi servqual dan kano model didapatkan hasil bahwa atribut yang harus dilakukan pengembangan adalah :

* Penerangan memadai dalam ruang pelayanan

* Sarana Untuk mengetahui keluhan dan saran pasien 
Atribut yang harus dilakukan perbaikan dan peningkatan adalah :

* Memiliki ruang tunggu yang cukup dan nyaman

* Jadwal Pelayanan yang tepat waktu

* Pemberian Pelayanan secara adil

* Daya Tanggap Tenaga Medis terhadap keluhan pasien

* Kemampuan tenaga medis dalam menjelaskan hasil pemeriksaan

Atribut yang harus dilakukan perbaikan adalah :

* Biaya Pelayanan kesehatan yang diberikan pada pasien terjangkau

* Lamanya waktu Pemeriksaan

* Kemudahan dalam menemui tenaga medis

* Kemampuan dan kecekatan tenaga medis dalam menanggapi keluhan pasien

* Kejelasan petugas dalam memberikan informasi

* Kejelasan informasi pelayanan

* Kemudahan pasien dalam mendapatkan informasi

3. Upaya perbaikan yang harus dilakukan terhadap dua klinik yang mengalami penurunan kualitas pelayanan selama 4 semester terakhir dari tahun 2017-2018 adalah sebagai berikut :

a) Penyelenggaraan pendidikan dan pelatihan dengan level skor kepentingan respon teknis $(730,14)$ atau berkontribusi sebesar $31 \%$ dalam usulan perbaikan.

b) Briefing orientasi kualitas pada tenaga medis level skor kepentingan respon teknis $(430,55)$ atau berkontribusi sebesar $18 \%$ dalam usulan perbaikan.

c) Program tenaga medis dan petugas teladan/terbaik level skor kepentingan respon teknis $(361,26)$ atau berkontribusi sebesar $15 \%$ dalam usulan perbaikan.

d) Pemberian kotak saran dan aduan level skor kepentingan respon teknis
$(232,56)$ atau berkontribusi sebesar $10 \%$ dalam usulan perbaikan.

e) Perbaikan sistem monitoring dan evaluasi kinerja dengan level skor kepentingan respon teknis $(200,91)$ atau berkontribusi sebesar $8 \%$ dalam usulan perbaikan.

\section{B. Saran}

Saran-saran yang dapat diberikan penulis dalam penelitian ini adalah :

1. Saran untuk perusahaan

a) Perusahaan melakukan perbaikan kualitas pelayanan berdasarkan usulan perbaikan yang didapatakan dalam penelitian ini

2. Saran untuk peneliti selanjutnya

1. Penyusunan kuesioner menggunakan servqual dan kano model diharapkan di desain dengan baik agar responden tidak bingung dalam pengisiannya.

2. Penerapan benchmarking pada HOQ lebih baik dilakukan, dalam penelitian ini tidak dilakukan karena obyek penelitian tidak memungkinkan untuk dilakukan benchmarking.

3. Pada penentuan responden sebaiknya responden adalah pelanggan/pasien tetap yang benar-benar memahami kualitas pelayanan di lokasi yang diteliti.

\section{DAFTAR PUSTAKA}

Anjar, P., \& Yulita, A. (2017). Integrating Kano Model and Quality Function Deployment for Designing Service of Hospital Front Office. Universitas Islam Indonesia: Intangible Capital, No. 15 Vol. 5.

Ariani, D. W. (2009). Manajemen Operasi Jasa. Yogyakarta: Graha Ilmu.

Arikunto, S. (2013). Manajemen Penelitian. Jakarta: Rineka Cipta. 
Cohen, L. (1995). Quality Function Deployment (How to Make QFD work of you). New York: Wesley Publishing Company.

Coleman, L. B. (2014). The CustomerDrivenOrganization: Employing the Kano Model. Florida: CRC Press.

Desiawan, V. A. (2010). Penerapan Quality Function Deployment dengan Mengadopsi Penggabungan Metode Service Quality dan Kano Model Dalam Upaya Meningkatkan Kualitas layanan Pada Bengkel Resmi ATPM. Depok: Universitas Indonesia : Tesis.

Ekawati, R., \& Triani, W. (2014). Analisis Pengendalian Kualitas Pelayanan Rawat Jalan di RSKM Menggunakan QFD. Seminar Nasional Sains dan Teknologi, ISSN 2407-1846.

Farah, A. N. (2018). Perancangan Perbaikan Sistem Layanan Publik dengan Integrasi Metode Servqual, Kano dan QFD (Studi Kasus: Kantor Kecamatan Ceper). Yogyakarta: Universitas Islam Indonesia : Tugas Akhir.

Gasperez, V. (2001). Total Quality Management. Jakarta: Gramedia Pustaka Utama.

Gunawan, R. (2015). Peningkatan Kualitas Layanan di Anugerah Copy Center Surabaya dengan Menggunakan Integrasi Service Quality dan Model Kano ke dalam Quality Function Deployment. Calyptra : Jurnal Ilmiah Mahasiswa Universitas Surabaya, No.1 Vol. 4.

Wahyuni \& Sulistiyowati, wiwik. (2015). Penentuan Prioritas Perbaikan Kualitas Layanan Kesehatan dengan Metode Servqual. JEMIS VOL.3 NO.1, ISSN 2338-3925.

Hilmansyah, D. (2016). Integrasi Metode Service Quality , Kano Model dan Quality
Function Deployment untuk Peningkatan Kualitas Pelayanan Sekolah Staf dan Komando Angkatan Laut. Universitas Pertahanan Indonesia: Jurnal Pertahanan, No.1 Vol. 6.

Irwan, \& Haryono, D. (2015). Pengendalian Kualitas Statistik (pendekatan Teoritis dan Aplikatif). Bandung: ALFABETA.

Kendampully, J., \& Solnet, D. (2015). Service Management Principles for Hospitality and Tourism. United States: Kendall/Hunt.

Kosasih, N. V., Sari, Y., \& Hidayat, M. A. (2016). Upaya Perbaikan Kualitas Layanan Dengan Menggunakan Integrasi Metode SERVQUAL, Model Kano dan QFD di Restoran Kapulaga Surabaya. Calyptra: Jurnal Ilmiah Mahasiswa Universitas Surabaya, No. 5 Vol. 1.

Maulana, F. N. (2010). Upaya Peningkatan Kualitas Pelayanan Unit Rawat Jalan Rumah Sakit Umum Daerah dengan Metode Integrasi Servqual dan Kano Model ke dalam Quality Function Deployment. Depok: Universitas Indonesia: Tugas Akhir.

Pemasaran, D. (2018). Laporan Kinerja Instansi Pemerintah (LKIP). Gresik: RSUD Ibnu SIna.

Prabasari, D. A., Amani, H., \& Wulandari, S. (2018). Perbaikan Kualitas Pelayanan Produk T-Cash di Kota Bandung Menggunakan Integrasi Metode EService Quality dan Model Kano. eproceeding of Engineering (hal. 2837). Bandung: Universitas Telkom.

Rahmana, A., Kamil, M., Soemantri, E., \& Olim, A. (2014). Integrating of SERVQUAL and Kano Model into QFD to Improve Quality of Simulation-Based Training on Project Management. Insan Akademika 
Publications (hal. 2301-4458). Bandung: Universitas Widyatama : International Journal of Basic and Applied Science.

Rangkuti, F. (2003). Konsep Pengukuran Kepuasan. Jakarta: Gramedia Pustaka Utama.

Sianturi, H. P., \& Singgih, M. L. (2011). Peningkatan Kualitas Pelayanan Kesehatan Pasien Unit Instalasi Rawat Jalan (IRJ) RUMIKTAL DR. Ramelan Surabaya dengan menggunakan metode servqual dan QFD. Prosiding Seminar Nasional Manajemen Teknologi XIV, -.

Sudaryono. (2017). Metodologi Penelitian. Jakarta: Rajawali Perss.

Supena, A. R., Suhendra, A. A., \& Tiara, A. R. (2017). Analisa Kebutuhan Layanan Biro Perjalanan Umrah Menggunakan Integrasi Servqual dan Model Kano di PT. XTZ. e-proceeding of Engineering (hal. 4286). Bandung: Universitas Telkom.

Supengat, G., \& Kustiani, N. A. (2016). Studi Atas Pelayanan Client Coordinator Pada Kantor Pelayanan Utama Bea dan Cukai Tipe A Tanjung Priok dengan Menggunakan Servual, Kano Model dan Quality Function Deployment. Politeknik Keuangan Negara: Sekolah Tinggi Akuntansi Negara.

Tjiptono, F., \& Candra, G. (2016). Service, Quality and Satisfaction Edisi 4. Yogyakarta: Andi Offset.

Wijaya, T. (2011). Manajemen Kualitas Jasa (Desain Servqual, QFD dan Kano disertai contoh Aplikasi dalam Kasus Penelitian). Jakarta: INDEKS.

Wijaya, T. (2018). Manajemen Kualitas Jasa (Desain Servqual, QFD dan Kano) Edisi 2. Jakarta: INDEKS 